\title{
Isolation and identification of biogenic amine-degrading probiotic lactic acid bacteria isolated from over-ripened kimchi
}

\author{
Eun-Seo Lim* \\ Department of Food Science and Nutrition, Tongmyong University, Busan 48520, Korea

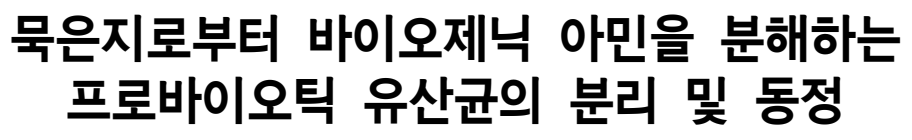 \\ 임은서* \\ 동명대학교 식품영양학과
}

\begin{abstract}
The aim of this study was to evaluate biogenic amines (BA)-forming and -degrading abilities of lactic acid bacteria (LAB) and yeasts isolated from over-ripened kimchi and to investigate probiotic characteristics of the BA-degrading and -degrading microorganism. There were significantly more BA-forming LAB and yeasts in over-ripened kimchi prepared with fish sauce or salted fish than sun-dried salt. The BA-forming ability of the microorganisms was highly strain-dependent. Among the isolated microorganisms, the BA degradation ability was found in LAB including Leuconostoc mesenteroides subsp. mesenteroides CML01, Enterococcus faecium KML12, Lactobacillus fermentum MML21, Lactobacillus sakei MML23, Enterococcus faecalis MML26, and Pediococcus pentosaceus SML34. However, all yeast tested did not show the BA degradtion ability. In addition, $L$. sakei MML23 and P. pentosaceus SML34 exhibited probiotic characteristics including tolerance to gastric acid and bile salt, adhesion capacity to intestinal epithelial cells, and antibiotic susceptibility. Furthermore, the bacteriocin produced by $L$. sakei MML23 and $P$. pentosaceus SML34 showed antibacterial activity against $E$. faecium KML15, Saccharomyces cerevisiae MMY28, and Lactobacillus brevis MML24. Consequently, the bacteriocin produced by probiotic $L$. sakei MML23 and $P$. pentosaceus SML34 seemed to be effective in reducing the risk of BA toxicity by inhibiting the growth of histamine, cadaverine, and putrescine-forming bacteria.
\end{abstract}

Key words : bacteriocin, biogenic amine, lactic acid bacteria, over-ripened kimchi

\section{서 론}

발효 식품은 “특정 미생물의 성장과 효소의 작용을 통해 성분이 전환된 식품이나 음료”로 정의된다(Dimidi 등, 2019). 육류, 어류, 유제품, 채소류, 두류, 곡류 등 다양한 식재료가 발효 식품 제조에 이용되고 있고, 발효에 관여하는 미생물의 종류, 영양 성분, 환경 등의 조건에 따라 다양한 발효 식품이
제조된다(Dimidi 등, 2019). 인류의 역사상 오래 전부터 이용 되어 온 발효 식품은 제조 과정 동안 유용 미생물에 의해 유 기산, 알코올 및 박테리오신 등의 항균 물질이 생산되어 유해 미생물의 오염 위험과 증식이 억제됨으로써 저장성이 연장되 고, 향미나 조직감과 같은 관능학적 특성과 기호도가 향상된 다(Dimidi 등, 2019). 많은 유익균은 발효 과정 동안 식품 원 료를 구성하는 화학 성분을 전환시켜 영양분의 생체이용률을

*Corresponding author. E-mail : limsm020@tu.ac.kr, Phone : +82-51-629-1714, Fax : +82-51-629-1709

Received 08 June 2020; Revised 28 September 2020; Accepted 13 October 2020.

Copyright (c) The Korean Society of Food Preservation.

This is an Open Access article distributed under the terms of the Creative Commons Attribution Non-Commercial License (http://creativecommons.org/licenses/by-nc/4.0) which permits unrestricted non-commercial use, distribution, and reproduction in any medium, provided the original work is properly cited. 
높이고, 생물학적 보존제로서 식품의 안전성을 강화시키며, 독성 물질 및 영양 저해 인자의 분해 및 생리활성 물질을 생 산하는 것으로 보고되고 있다(Tamang 등, 2016). 게다가 발 효 스타터 미생물의 대사 산물들은 심혈관 및 위장관 질환, 암, 알레르기, 골다공증, 유당불내증 및 당뇨 등 각종 질병 예 방의 효과도 밝혀지고 있다(Tamang 등, 2016).

이에 반해 다양한 기능성과 유용성이 알려진 발효 식품일 지라도 우리의 건강을 위협하는 독성 물질인 바이오제닉 아 민(biogenic amines, BA)의 생성량이 상당히 높다는 점에 주 목해야 한다. $\mathrm{BA}$ 는 발효에 관여하는 미생물에 의해 전구체 아미노산의 탈탄산화 혹은 아미노산의 아미노기전이효소 활 성으로 인한 알데히드와 케톤의 아미노기 전이반응에 따라 생성되는 저분자 유기화합물이다. BA는 호르몬, 알칼로이드, 핵산 및 단백질 합성을 위한 전구체인 질소원으로서 체온 조 절, 영양분 흡수 및 혈압 강하 등의 생명 유지를 위해 필요하 므로 소량의 BA 섭취는 건강에 유해하지 않다(Tamang 등, 2016). 하지만 유전적 결함, 위장 질환이나 모노아민 산화효 소 억제제와 같은 약물 복용 등에 의하여 아민 산화효소의 활성이 낮으면 히스타민 과민증을 유발하게 된다(Tamang 등, 2016). 또한, 과도한 양의 BA 섭취 시 호흡곤란, 오심, 두통, 발진 및 혈압 상승 등의 세균성 식중독과 유사한 증상 을 초래하게 된다(Ladero 등, 2010).

우리나라 대표적인 발효 식품의 하나인 김치는 다량의 비 타민, 무기질 및 기타 기능성 성분을 생산하여 항암, 항산화, 항동맥경화, 항당뇨 및 항비만 등 건강에 이로운 여러 가지 활성을 발휘한다(Park 등, 2014). 김치 발효의 주체인 유산균 은 프로바이오틱 활성으로 인하여 장 기능 개선, 항염증, 항 균, 항콜레스테롤, 항노화 활성 및 면역 기능 강화 효과를 나 타낸다(Zhao 등, 2019). 하지만 김치와 같은 발효 채소류에는 미생물의 증식과 탈탄산 효소의 활성에 따라 상당량의 BA가 검출되고 있다(Montet 등, 2014). Leuconostoc mesenteroides 등은 채소류의 유산 발효에 관여하는 대표적인 유산균으로 일부 아미노산을 탈탄산화 시켜 $\mathrm{BA}$ 를 생성하는 것으로 확인 된 바 있다(Garcia-Ruiz 등, 2011). Mah 등(2004)은 시판되는 8종의 김치로부터 푸트레신, 카다베린, 히스타민 및 티라민 등의 $\mathrm{BA}$ 가 검출되었음을 확인하였고, 이는 부재료인 액젓이 유해 아민 생성에 중요한 역할을 한다고 설명하였다. 또한, 파김치와 갓김치로부터 분리된 Lactobacillus brevis가 티라 민, 베타-페닐에틸아민, 푸트레신 및 카다베린 등을 생성하는 원인균인 것으로 확인된 바 있다(Lee 등, 2019). 반면 Lactobacillus plantarum CAU3823은 아민 산화효소를 생산 함으로써 중국 쌀 와인의 발효 후기에 BA 함량을 약 $40 \%$ 감소시켜 발효 식품의 독성 위험을 유의하게 낮춘 것으로 알 려졌다(Niu 등, 2019). BA의 생성 및 분해능은 유산균뿐만 아
니라, 효모에 의해서도 확인되었는데, 발효 유제품으로부터 분리 된 Debaryomyces 속, Yarrowia 속, Candida 속, Kluyveromyces 속, Saccharomyces 속 등의 효모도 $\mathrm{BA}$ 를 생성하는 것으로 알려진 바 있다(Benkerroum, 2016). 하지만 Baumlisberger 등(2015)은 Debaryomyces hansenii H525와 Yarrowia lipolytica 등의 일부 효모로부터 BA 분해능이 밝혀져 BA의 감소를 위한 스타터로서의 활용 가치가 높다고 보고하였다.

지금까지 유제품이나 두류 가공품 등 단백질 함량이 높거 나 김치 등의 발효 채소류 내에 존재하는 유산균과 효모가 $\mathrm{BA}$ 함량에 미치는 영향을 조사한 연구 결과는 다수 보고되 었다(Doeun 등, 2017; Spano 등, 2010). 일반적으로 발효 기 간이 길어짐에 따라 $\mathrm{BA}$ 함량은 증가되는 것으로 알려져 있 음에도 불구하고(Um 등, 2016), 오랜 기간 숙성시킨 묵은지 내 $\mathrm{BA}$ 의 함량 및 분리된 유산균과 효모의 $\mathrm{BA}$ 생성 및 분해 능에 관한 연구 결과는 부족하다. 따라서 본 연구에서는 김치 제조 시 첨가된 젓갈별 묵은지로부터 분리된 유산균과 효모 의 $\mathrm{BA}$ 생성 및 분해능을 측정하고, 분해 활성을 나타내는 균 주의 발효식품 스타터로서의 활용 가능성 평가를 위한 프로 바이오틱 활성을 조사하였다.

\section{재료 및 방법}

\section{김치 제조}

전통 시장에서 구입한 배추는 반으로 자른 다음 배추 $1 \mathrm{~kg}$ 당 $10 \%(\mathrm{w} / \mathrm{v})$ 천일염 용액에 담궈서 상온에 두고 약 15 시간 침지시켰다. 흐르는 수돗물로 3 회 깨끗하게 헹군 다음 3 시간 가량 방치하여 물기를 제거하였다. 고춧가루 $(3.5 \%)$, 마늘 $(2.5 \%)$, 생강 $(0.5 \%)$, 양파 $(3.0 \%)$, 찹쌀풀 $(3.0 \%)$ 및 젓갈 $(2.5 \%)$ 을 혼합하고, 분쇄기(SMKANB-4000, PN, Ansan, Korea)로 곱게 갈아서 만든 양념을 절임 배추 $(85 \%)$ 에 골고루 묻혀 김 치를 담궜다. 젓갈은 전통 시장에서 구입한 까나리와 멸치 액 젓 및 새우젓갈을 각각 사용하였다. 담근 김치는 상온에서 하 룻밤 정도 방치한 다음 $2^{\circ} \mathrm{C}$ 냉장고에서 12 개월간 보관하여 제조한 묵은지를 실험에 사용하였다.

\section{유산균 동정}

시료 $50 \mathrm{~g}$ 에 인산완충용액(phosphate buffer saline, PBS, $\mathrm{pH}$ 7.0) $450 \mathrm{~mL}$ 를 가한 다음 약 3 분간 스토마커 $(3 \mathrm{M}$, Maplewood, MN, USA)로 균질화한 시료 용액을 $1 \%(\mathrm{w} / \mathrm{v})$ $\mathrm{CaCO}_{3}$ 가 첨가된 Lactobacilli MRS agar(BD Difco Co.) 평 판배지에 도말 접종하고 $37^{\circ} \mathrm{C}$ 에서 48 시간 배양하였다. 집락 주변에 투명한 환을 생성하는 균주를 선발하여 MRS agar(BD Difco Co., Sparks, MD, USA) 평판배지 상에서 순 수 분리 배양하였다. 유산균은 $\operatorname{Lim}(2016)$ 의 방법에 따라 
DNA extraction kit(Qiagen, Hilden, Germany)로 균주의 $\mathrm{DNA}$ 를 추출 정제한 후 $27 \mathrm{~F}\left(5^{\prime}\right.$-AGAGTTTGATCCTGGCT CAG-3')와 1492R(5'-GGTTACCTTGTTACGACTT-3') 프라 이머를 사용하여 중합효소연쇄반응(polymerase chain reaction, PCR, Bio-Rad Laboratories Inc., Foster City, California, $\mathrm{USA})$ 으로 초기 변성 $\left(94^{\circ} \mathrm{C}, 3\right.$ 분), 변성( $94^{\circ} \mathrm{C}, 2$ 분), 풀림( $42^{\circ} \mathrm{C}$, 1 분), 신장 $\left(72^{\circ} \mathrm{C}, 2\right.$ 분), 연장 $\left(72^{\circ} \mathrm{C}, 7\right.$ 분) 순으로 36 회 반복시 켜 DNA를 증폭시켰다. PCR 산물은 purification kit(Qiagen) 로 정제한 후 National Center for Biotechnology Information (NCBI)의 BLAST search(http://www.ncbi.nlm.nih.gov)를 통 해 유전자 염기서열을 분석하고 상동성을 비교하여 동정하였 다.

\section{효모 동정}

앞서 균질화한 시료 용액을 Yeast Glucose Chloramphenicaol(YGC) agar(BD Difco Co.) 평판배지에 도말 접종하고, $25^{\circ} \mathrm{C}$ 에서 48 시간 배양하여 생성된 집락을 $\mathrm{YPD}$ (yeast extract $1 \%$, peptone $2 \%$, dextrose $2 \%$, agar $2 \%, \mathrm{w} / \mathrm{v}$ ) 배지에서 순수 분리 배양한 효모는 Min 등(2012) 방법에 따라 동정하였다. 즉, YPD broth에 접종하여 $30^{\circ} \mathrm{C}$ 에서 24시간 동안 배양한 후 원심분리 $\left(7,000 \times g, 10\right.$ 분, $\left.4^{\circ} \mathrm{C}\right)$ 하였다. 세포를 TE buffer(10 $\mathrm{mM}$ Tris-HCl, pH 8.0; 1 mM EDTA)에 현탁시켜 genomic DNA purification kit(Promega, Madison, WI, USA)로 주형 $\mathrm{DNA}$ 를 제조하였다. $\mathrm{PCR}$ 에 사용될 $26 \mathrm{~S} \mathrm{rDNA}$ 의 $\mathrm{D} 1 / \mathrm{D} 2$ 도 메인을 증폭시키기 위해 NL-1(5'-GCATATCAATAAGCGGA GGAAAAG-3')과 NL-4(5'-G GTCCGTGTTTCAAGACGG3') 프라이머, ITS1/5.8S rDNA/ ITS2 도메인은 ITS-1(5'-TC CGTAGGTGAACCTGCG-3')과 ITS-4(5'-TCCTCCGCTTA TTGATATGC-3') 프라이머를 사용하였다. PCR Thermal cycler(Bio-Rad Laboratories Inc.)에서 초기 변성( $94^{\circ} \mathrm{C}, 3$ 분), 변성 $\left(94^{\circ} \mathrm{C}, 2\right.$ 분), 풀림 $\left(42^{\circ} \mathrm{C}, 1\right.$ 분), 신장 $\left(72^{\circ} \mathrm{C}, 2\right.$ 분), 연장 $\left(72^{\circ} \mathrm{C}\right.$, 7 분) 순으로 36 회 반복시켜 DNA를 증폭시켰다. PCR 산물은 purification kit(Qiagen)로 정제한 후 $\mathrm{NCBI}$ 의 BLAST search 를 통해 유전자 염기서열을 분석하고 상동성을 비교하여 동 정하였다.

\section{$\mathrm{BA}$ 생성능 측정}

순수분리 및 동정된 유산균과 효모의 BA 생성능은 Eerola 등(1993)과 Mah 등(2003)의 방법에 따라 측정하였다. MRS broth에서 배양된 유산균 전 배양액 $(0.1 \mathrm{~mL})$ 은 $\mathrm{BA}$ 생성을 위 한 합성배지 $(1 \mathrm{~L}$ 당 meat extract $8 \mathrm{~g}$, tryptone $5 \mathrm{~g}$, yeast extract $4 \mathrm{~g}$, glucose $1.5 \mathrm{~g}$, fructose $1 \mathrm{~g}$, Tween $800.5 \mathrm{~g}$, $\mathrm{MgSO}_{4} 0.2 \mathrm{~g}, \mathrm{FeSO}_{4} 0.04 \mathrm{~g}, \mathrm{MnSO}_{4} 0.05 \mathrm{~g}, \mathrm{CaCO}_{3} 0.1 \mathrm{~g}$, tyrosine $2 \mathrm{~g}$, histidine $2 \mathrm{~g}$, ornithine $2 \mathrm{~g}$, lysine $2 \mathrm{~g}$, pyridoxal 5-phosphate $0.25 \mathrm{~g}, \mathrm{pH} 5.5$ ) 상에서 $28^{\circ} \mathrm{C}, 5$ 일간 배양하였다. 한편, 효모는 YPD broth에 접종한 후 배양시켜 얻은 전 배양 액 $(0.1 \mathrm{~mL})$ 을 유산균과 동일한 $\mathrm{BA}$ 생성 합성배지 상에 접종 한 다음, $28^{\circ} \mathrm{C}, 5$ 일간 배양하였다. 유산균과 효모의 배양액은 원심분리 $(7,000 \times g, 10$ 분)하여 상등액만 취해 여과 제균한 다 음 Han 등(2007)의 방법을 일부 변형하여 BA 함량을 측정하 였다. 즉, 시료 $(5 \mathrm{~g})$ 에 $0.1 \mathrm{~N} \mathrm{HCl}(20 \mathrm{~mL})$ 을 가하여 균질화 한 다음 원심분리 $(7,000 \times g, 20$ 분 $)$ 하여 상등액을 회수하였다. 침전물은 반복 조작을 통해 최종 $50 \mathrm{~mL}$ 에 맞춰 시료 용액으 로 사용하였다. 여과 제균 $(0.45 \mu \mathrm{m}$ membrane filter, Millipore Co., Bedford, MA, USA)한 시료 용액에 BA 혼합 표준 용액 (cadaverine, histamine, putrescine, tyramine, $500 \mathrm{mg} / \mathrm{L}$ )과 0.4 M perchloric acid (Merck, Kenilworth, NJ, USA, $9 \mathrm{~mL}$ ) 를 첨가한 다음 진탕 혼합 후 원심분리 $(3,000 \times g, 10$ 분)하였 다. 상등액을 모아 여과(Whatman paper No.1, Piscataway, $\mathrm{NJ}, \mathrm{USA})$ 하고, 그 여액 $(1 \mathrm{~mL})$ 에 $2 \mathrm{~N}$ sodium hydroxide(200 $\mu \mathrm{L})$ 와 sodium bicarbonate 포화 용액 $(300 \mu \mathrm{L})$ 을 가하고 아세 톤에 용해시킨 dansyl chloride(Sigma-Aldrich, $10 \mathrm{mg} / \mathrm{mL}, 2$ $\mathrm{mL}$ )를 첨가하여 $40^{\circ} \mathrm{C}$ 에서 약 45 분간 반응시켰다. $25 \%(\mathrm{v} / \mathrm{v})$ ammonium hydroxide $(100 \mu \mathrm{L})$ 를 가해 잔존하는 dansyl chloride를 제거하고, 상온에서 약 30 분간 방치하였다. Acetonitrile을 가하여 최종 $5 \mathrm{~mL}$ 에 맞춘 다음 원심분리 $(2,500 \times g, 5$ 분 $)$ 하여 얻은 상등액은 $0.22 \mu \mathrm{m}$ membrane filter(Millipore)로 여과하여 dansyl 유도체화 시켰다. NovaPak $\mathrm{C}_{18}$ 컬럼(150×3.9 mm, $4 \mu \mathrm{m}$, Waters, Milford, MA, USA)을 연결한 HPLC (Shimadzu, Kyoto, Japan)로 시료 내 $\mathrm{BA}$ 함량을 측정하였다. 이동상 $\mathrm{A}$ 용액으로는 $0.1 \mathrm{M}$ ammonium acetate와 B 용액으로는 acetonitrile을 사용하였고, 시료 $10 \mu \mathrm{L}$ 를 주입하여 유속은 $1 \mathrm{~mL} / \mathrm{min}$ 으로 조정하였으며, 컬럼 온도 $40^{\circ} \mathrm{C}$ 에서 분석하였다.

\section{$\mathrm{BA}$ 분해능 측정}

유산균과 효모의 BA 분해능은 Lee 등(2015)의 방법에 따 라 측정하였다. 유산균은 MRS broth에서 $37^{\circ} \mathrm{C}, 24$ 시간, 효모 는 YPD broth에서 $30^{\circ} \mathrm{C}, 24$ 시간 동안 각각 배양하여 원심분 리 $(7,000 \times \mathrm{g}, 10$ 분 $)$ 하여 모은 세포를 $\mathrm{PBS}(\mathrm{pH} 7.0)$ 에 현탁시 켜 초기 균수를 $1.0 \times 10^{6} \mathrm{CFU} / \mathrm{mL}$ 로 조정하였다. 세포 현탁액 $(1 \mathrm{~mL})$ 에 $\mathrm{BA}$ (cadaverine dihydrochloride, histamine dihydrochloride, putrescine dihydrochloride, tyramine hydrochloride, $0.1 \%, \mathrm{w} / \mathrm{v})$ 을 첨가한 MRS broth와 YPD broth에 유산균과 효모를 각각 접종한 후 $30^{\circ} \mathrm{C}$ 에서 5 일간 전 배양하 였다. 유산균과 효모의 배양액 $(1 \mathrm{~mL})$ 을 $\mathrm{BA}(50 \mathrm{ppm})$ 가 첨가 된 MRS broth와 $\mathrm{YPD}$ broth에 각각 접종하고, $30^{\circ} \mathrm{C}$ 에서 48 시간 동안 본 배양하였다. 배양액 $(1 \mathrm{~mL})$ 에 $\mathrm{BA}$ 혼합 표준용 
액(500 mg/L) 및 $0.4 \mathrm{M}$ perchloric acid $(9 \mathrm{~mL})$ 를 첨가하여 진탕 혼합한 다음 원심분리 $(3,000 \times g, 10$ 분 $)$ 하였다. 상등액을 여과(Whatman paper No. 1, Whatman, Maidstone, Kent, UK) 해서 앞서 언급한 방법으로 유도체화 후 HPLC로 잔존하는 $\mathrm{BA}$ 의 함량을 측정하였다. $\mathrm{BA}$ 분해능 $(\%)$ 계산식[(초기 $\mathrm{BA}$ 함량 - 잔존 $\mathrm{BA}$ 함량) / 초기 $\mathrm{BA}$ 함량 $\times 100]$ 에 대입하여 측정하였다.

\section{인공 소화액에 대한 저항성 측정}

$\operatorname{Lim}(2019)$ 의 방법에 따라 BA 분해능을 나타낸 균주는 증 균용 액체배지에서 $37^{\circ} \mathrm{C}, 24$ 시간 배양하였다. 배양액을 원심 분리 $\left(7,000 \times g, 10\right.$ 분, $\left.4^{\circ} \mathrm{C}\right)$ 하여 세포를 회수하고 $\mathrm{PBS}(\mathrm{pH}$ 7.0)를 가하여 2회 세척하였다. 세포수는 $1.0 \times 10^{8} \mathrm{CFU} / \mathrm{mL}$ 로 조정하여 인공 위액 $\left[\mathrm{NaCl} 125 \mathrm{~mL}, \mathrm{KCl} 7 \mathrm{mM}, \mathrm{NaHCO}_{3} 45\right.$ $\mathrm{mM}$, 펩신(Sigma-Aldrich) $1 \mathrm{mg} / \mathrm{mL}, \mathrm{pH}$ 2.0]에 접종한 다음 $37^{\circ} \mathrm{C}$ 에서 2 시간 배양하였다. 배양액 내 잔존하는 균수는 배 양용 평판배지 상에서 표준한천평판배양법으로 측정하였다. 한편, 인공 위액 내에서 잔존하는 세포수로 조정한 현탁액을 $1.0 \%(\mathrm{w} / \mathrm{v})$ bile salts(Sigma-Aldrich) 용액에 접종하였다. 3 $7^{\circ} \mathrm{C}$ 에서 3 시간 배양한 후 배양용 평판배지 상에서 표준한천 평판배양법으로 균수를 측정하였고, 인공위액 및 담즙액에서 의 생존율 $(\%)$ 로 나타내었다.

\section{장내 상피세포에 대한 부착능 조사}

$\operatorname{Lim}(2019)$ 의 방법에 따라 장내 상피세포에 대한 부착능 조사를 위해 Caco-2 cell(Korean Cell Line Bank)을 사용하였 다. Dulbecco's modified Eagle's minimal essential medium (DMEM, Sigma-Aldrich) 배지에 10\% (v/v) fetal bovine serum(Gibco, Rockvile, MD, USA), 2 mM L-glutamine, 1 $\mathrm{mM}$ sodium pyruvate, $100 \mathrm{U} / \mathrm{mL}$ penicillin, $0.1 \mathrm{mg} / \mathrm{mL}$ streptomycin을 첨가한 다음 Caco-2 cell을 접종하고, $5 \%$ $\mathrm{CO}_{2}, 37^{\circ} \mathrm{C}$ 에서 monolayer를 형성할 때까지 배양하였다. DMEM 배지를 분주한 6-well culture plate (Falcon, Beckton Dickinson, Sparks, $\mathrm{MD}$, USA)에 $\mathrm{PBS}(\mathrm{pH}$ 7.0)로 세척한 Caco-2 cell $\left(1.0 \times 10^{5}\right.$ cells $\left./ \mathrm{mL}\right)$ 을 접종한 다음 동일한 조건에 서 2 시간 배양하였다. 균 배양액을 원심분리 $(7,000 \times g, 10$ 분, $\left.4^{\circ} \mathrm{C}\right)$ 하고 $\mathrm{PBS}(\mathrm{pH}$ 7.0)로 세척한 세포를 DMEM에 현탁하여 균수를 $1.0 \times 10^{8} \mathrm{CFU} / \mathrm{mL}$ 로 조정하고, 각 well에 접종하여 3 $7^{\circ} \mathrm{C}$ 에서 2시간 동안 배양하였다. Caco-2 cell에 부착되지 않 은 BA 분해균을 제거하고 난 후 trypsin- EDTA 용액으로 탈 착시켜 $\mathrm{PBS}(\mathrm{pH}$ 7.0)로 세척한 후 배양용 평판배지 상에서 표 준한천평판배양법으로 $\mathrm{BA}$ 분해 균수를 측정하였다.

\section{항생제에 대한 감수성 측정}

$\mathrm{BA}$ 분해능을 나타낸 균주의 항생제에 대한 감수성은 최소 억제농도(minimum inhibitory concentration, MIC)법(Bauer 등, 1966)으로 측정하였다. 증균 배양액은 원심분리 $(7,000$ $\times g, 10$ 분, $\left.4^{\circ} \mathrm{C}\right)$ 를 통해 세포를 모아 $\mathrm{PBS}(\mathrm{pH} 7.0)$ 로 세척 후 세포수는 $1.0 \times 10^{6} \mathrm{CFU} / \mathrm{mL}$ 로 조정하였다. $50^{\circ} \mathrm{C}$ 전후로 식힌 고체배지(agar $1.0 \%, \mathrm{w} / \mathrm{v})$ 에 세포 현탁액 $(1 \%, \mathrm{v} / \mathrm{v})$ 을 접종하 고 혼합한 후 평판배지 위에 중층하여 응고시켰다. 암피실린, 에리스로마이신, 카나마이신, 페니실린, 스트렙토마이신, 테 트라사이클린 및 반코마이신 등의 항생제(Sigma-Aldrich) stock으로부터 2진 희석법으로 농도를 맞춘 다음 paper disc (Ф $8 \mathrm{~mm}$, Toyo Co., Japan)에 $50 \mu \mathrm{L}$ loading하고, 균이 접종 된 평판배지에 올렸다. $37^{\circ} \mathrm{C}, 24$ 시간 배양 후 disc 주위에 저 해환을 생성하는 항생제의 최소 농도를 측정하였다.

\section{박테리오신 활성 측정}

$\mathrm{BA}$ 분해균은 $37^{\circ} \mathrm{C}$ 에서 24 시간 배양하여 얻은 배양액을 원심분리 $\left(7,000 \times g, 10\right.$ 분, $\left.4^{\circ} \mathrm{C}\right)$ 하여 배양 상등액만을 모은 뒤 $6 \mathrm{~N} \mathrm{NaOH}$ 로 $\mathrm{pH}$ 6.5에 맞추고 카탈라아제 $(1 \mathrm{mg} / \mathrm{mL}$, SigmaAldrich)를 처리하였다. $50 \%(\mathrm{w} / \mathrm{v})$ 황산암모늄을 첨가하고 $4^{\circ} \mathrm{C}$ 에서 교반하면서 overnight 동안 단백질을 침전시킨 다음 원심분리 $\left(12,000 \times g, 30\right.$ 분, $\left.4^{\circ} \mathrm{C}\right)$ 하였다. 침전물을 모아 20 $\mathrm{mM} \mathrm{PBS}(\mathrm{pH}$ 6.5)에 현탁시키고, 투석막(molecular weight cut-off $=1,000 \mathrm{Da}$, Spectrum, Laguna Hils, CA, USA)으로 $4^{\circ} \mathrm{C}$ 에서 24 시간 동안 투석하였다. 황산암모늄 침전법으로 농 축한 시료를 carboxy-methyl sepharose CL-6B(CM-Sepharose CL-6B, Pharmacia Biotech., Uppsala, Sweden) 양이온 교환 수지를 이용하여 부분 정제하였다. 즉, $20 \mathrm{mM} \mathrm{Na}$-phosphate buffer(pH 6.0)로 평형화시킨 다음 CM sepharose CL-6B column $(1.6 \times 23 \mathrm{~cm})$ 에 투석한 용액 $(4 \mathrm{~mL})$ 를 주입하고 $1 \mathrm{M}$ Na-phosphate buffer(pH 6.0)로 linear salt gradient 방법으로 수지에 단백질을 용출시켜 분획 $(4.5 \mathrm{~mL})$ 을 회수하여 항균 활 성을 측정하였다(Lee 등, 2005). 항균력 측정을 위한 지시 균 주는 본 연구에 사용된 김치 시료로부터 분리된 $\mathrm{BA}$ 생성 유 산균과 효모를 사용하였다. 이들은 MRS broth(BD Difco $\mathrm{Co}$.)와 YM broth(BD Difco Co.) 각각의 증균배지에서 배양 한 배양액을 원심분리 $\left(7,000 \times g, 10\right.$ 분, $\left.4^{\circ} \mathrm{C}\right)$ 하여 모은 세포를 $\mathrm{PBS}\left(\mathrm{pH}\right.$ 7.0)로 2 회 세척하고, 세포수를 $1.0 \times 10^{5} \mathrm{CFU} / \mathrm{mL}$ 로 조정하였다. 조 박테리오신 용액은 증균배지 상에서 이진 희 석하여 microtiter plate(Falcon, Beckton Dickinson)에 분주한 다음 지시 균주의 세포 현탁액을 접종하여 $37^{\circ} \mathrm{C}$ 에서 24 시간 배양하였다. 대조구는 조 박테리오신 용액 대신에 $\mathrm{PBS}(\mathrm{pH}$ 7.0)를 첨가한 후 배양하였다. 배양 후 microplate reader (BioTek, Inc., Seoul, Korea)로 $600 \mathrm{~nm}$ 의 파장에서 측정된 대조구 흡광도의 $50 \%$ 에 이르는 조 박테리오신 용액의 최대 
희석배수 역수를 박테리오신 활성(arbitray units, $\mathrm{AU})$ 으로 계산하였다.

\section{$\mathrm{BA}$ 생성량에 대한 박테리오신 용액의 영향 측정}

BA 생성량에 대한 박테리오신 용액의 영향은 Shakila 등 (1996)의 방법을 일부 변형하여 측정하였다. BA 생성균은 $0.0005 \%$ pyridoxal- $\mathrm{HCl}$ (Sigma-Aldrich)과 $0.5 \%$ L-histidine monohydrochloride monohydrate, L-lysine monohydrochloride, L-ornithine monohydrochloride 혹은 L-tyrosine hydrochloride (Sigma-Aldrich)를 첨가한 Trypticase Soy Broth(TSB, BD $\mathrm{Difco} \mathrm{Co}$.)에 접종한 다음 $35^{\circ} \mathrm{C}$ 에서 24 시간 배양하였다. 배 양액 $(1 \mathrm{~mL})$ 을 박테리오신 용액(100 AU/mL)과 아미노산(50 $\mathrm{ppm})$ 이 첨가된 $\mathrm{TSB}(5 \mathrm{~mL})$ 에 접종 후 $35^{\circ} \mathrm{C}$ 에서 24 시간 배양 하였다. 배양액을 원심분리 $\left(7,000 \times g, 10\right.$ 분, $\left.4^{\circ} \mathrm{C}\right)$ 한 다음 상 등액은 $0.22 \mu \mathrm{m}$ membrane filter(Millipore로 여과한 후 앞서 언급한 방법에 따라 $\mathrm{HPLC}$ 를 사용하여 BA 생성량의 저해율 (\%)을 측정하였다.

\section{결과 및 고찰}

\section{젓갈 종류별 묵은지로부터 유산균 및 효모의 분리 동정}

천일염 및 3 종의 액젓과 젓갈로 담근 김치를 12 개월 동안 발효시킨 묵은지로부터 분리된 BA 생성능 혹은 분해능을 나 타낸 유산균과 효모의 동정 결과는 Table 1 및 Table 2 와 같 다. 천일염으로 제조 후 발효시킨 묵은지로부터 분리된 유산 균과 효모는 각각 L. mesenteroides subsp. mesenteroides CML01(98.6\%), L. plantarum CML02(99.0\%) 및 Saccharomyces cerevisiae CMY03(97.0\%)으로 확인되었다. 까나리 액젓을 첨가하여 발효시킨 묵은지로부터는 $L$. brevis $\mathrm{KML} 11$ (98.2\%), Enterococcus faecium KML12(100.0\%), Weissella confuse KML13(99.9\%), Pediococcus pentosaceus KML14 (99.0\%), E. faecium KML15 (97.0\%), Zygosaccharomyces mellis KMY16(99.0\%), Pichia fermentans KMY17(96.8\%) 로 확인되었다. 멸치 액젓을 첨가하여 발효시킨 묵은지로 부터는 Lactobacillus fermentum MML21(100.0\%), L.

Table 1. Identification of lactic acid bacteria isolated from over-ripened kimchi prepared with different kinds of salted and fermented seafoods using $16 \mathrm{~S}$ rRNA gene sequence analysis

\begin{tabular}{|c|c|c|c|c|}
\hline \multirow{2}{*}{ Source } & \multirow{2}{*}{ LAB } & \multicolumn{3}{|l|}{ 16S rRNA sequencing } \\
\hline & & Related strain in NCBI & Accession No. & Similarity $(\%)$ \\
\hline \multirow{2}{*}{$\begin{array}{l}\text { Over-ripened kimchi } \\
\text { prepared with } \\
\text { sun-dried salt }\end{array}$} & CML01 & Leuconostoc mesenteroides subsp. mesenteroides TW8-1 & KJ026579 & 98.6 \\
\hline & CML02 & Lactobacillus plantarum FY1 & KY039178 & 99.0 \\
\hline \multirow{5}{*}{$\begin{array}{l}\text { Over-ripened kimchi } \\
\text { prepared with } \\
\text { 'Kanari-aekjeot' }\end{array}$} & KML11 & Lactobacillus brevis $12 \mathrm{~N}-1$ & MG676651 & 98.2 \\
\hline & KML12 & Enterococcus faecium $\mathrm{C} 228$ & AB246407 & 100.0 \\
\hline & KML13 & Weissella confusa R003 & KF312398 & 99.9 \\
\hline & KML14 & Pediococcus pentosaceus L105 & KJ649285 & 99.0 \\
\hline & KML15 & Enterococcus faecium DJ1 & GU358405 & 97.0 \\
\hline \multirow{6}{*}{$\begin{array}{l}\text { Over-ripened kimchi } \\
\text { prepared with } \\
\text { 'Myeolchi- } \\
\text { aekjeot' }\end{array}$} & MML21 & Lactobacillus fermentum LMEM 5 & MK418591 & 100.0 \\
\hline & MML22 & Leuconostoc mesenteroides AHL9a & MK262982 & 99.9 \\
\hline & MML23 & Lactobacillus sakei WJ1 & KM267630 & 98.3 \\
\hline & MML24 & Lactobacillus brevis $\mathrm{Z3}$ & KX608718 & 97.5 \\
\hline & MML25 & Lactobacillus plantarum S9 & MF197402 & 100.0 \\
\hline & MML26 & Enterococcus faecalis SLDL-211 & MH779826 & 100.0 \\
\hline \multirow{5}{*}{$\begin{array}{l}\text { Over-ripened kimchi } \\
\text { prepared with } \\
\text { 'Saeu-jeot' }\end{array}$} & SML31 & Leuconostoc mesenteroides PC13 & EF579730 & 99.0 \\
\hline & SML32 & Lactobacillus brevis $42 \mathrm{~K}$ & KU746859 & 98.9 \\
\hline & SML33 & Lactobacillus plantarum MS & KP874187 & 100.0 \\
\hline & SML34 & Pediococcus pentosaceus L43 & MN904850 & 99.3 \\
\hline & SML35 & Lactobacillus sakei MG5333 & MN368591 & 99.5 \\
\hline
\end{tabular}


Table 2. Identification of yeasts isolated from over-ripened kimchi prepared with different kinds of salted and fermented seafoods using 26S rRNA gene sequence analysis

\begin{tabular}{|c|c|c|c|c|}
\hline \multirow{2}{*}{ Source } & \multirow{2}{*}{ Yeast } & \multicolumn{3}{|c|}{ 26S rRNA sequencing } \\
\hline & & Related strain in NCBI & Accession No. & Similarity $(\%)$ \\
\hline $\begin{array}{l}\text { Over-ripened kimchi prepared } \\
\text { with sun-dried salt }\end{array}$ & CMY03 & Saccharomyces cerevisiae SFM33 & MG017574 & 97.0 \\
\hline \multirow{2}{*}{$\begin{array}{l}\text { Over-ripened kimchi prepared } \\
\text { with 'Kanari-aekjeot' }\end{array}$} & KMY16 & Zygosaccharomyces mellis ML534 & KC692235 & 99.0 \\
\hline & KMY17 & Pichia fermentans NM816 & MH704184 & 96.8 \\
\hline \multirow{3}{*}{$\begin{array}{l}\text { Over-ripened kimchi prepared } \\
\text { with 'Myeolchi-aekjeot' }\end{array}$} & MMY27 & Saccharomyces cerevisiae NQ4-3 & GU565198 & 98.3 \\
\hline & MMY28 & Pichia membranefaeciens IFO 10215 & AB019215 & 99.2 \\
\hline & MMY29 & Candida versatilis $\mathrm{OH} 3 \mathrm{G} 1$ & AB196212 & 100.0 \\
\hline \multirow{2}{*}{$\begin{array}{l}\text { Over-ripened kimchi prepared } \\
\text { with 'Saeu-jeot' }\end{array}$} & SMY36 & Debaryomyces hansenii WC13 & AB436429 & 98.0 \\
\hline & SMY37 & Pichia membranefaeciens NRRL Y-2026 & EF550227 & 99.9 \\
\hline
\end{tabular}

mesenteroides MML22(99.9\%), Lactobacillus sakei MML23(98.3\%), L. brevis MML24(97.5\%), L. plantarum MML25(100.0\%), Enterococcus faecalis MML26(100.0\%), S. cerevisiae MMY27(98.3\%), Pichia membranefaeciens MMY28(99.2\%), Candida versatilis MMY29(100.0\%)로 확 인되었다. 새우젓갈을 넣어 발효시킨 묵은지로부터는 $L$. mesenteroides SML31(99.0\%), L. brevis SML32(98.9\%), L. plantarum SML33(100.0\%), P. pentosaceus SML34(99.3\%), L. sakei SML35(99.5\%), D. hansenii SMY36(98.0\%), $P$. membranefaeciens SMY37(99.9\%)로 확인되었다. 분리된 유 산균과 효모의 종류는 묵은지 시료에 따라 유의한 차이가 있 었는데, 이는 김치 주 · 부원료 및 제조와 발효 환경의 차이에 기인하는 것으로 판단된다.

Park 등(2010)은 $4^{\circ} \mathrm{C}$ 에서 발효시킨 김치의 초기 단계의 주 요 유산균으로는 W. koreensis와 L. brevis가 우점종으로 하였 고, 묵은지 시료로부터는 Leuconostoc gelidum과 L. sakei subsp. sakei가 주를 이룬다고 밝혔다. Lee와 Lee(2011)는 $L$. mesenteroides, L. plantarum 및 L. sakei는 묵은지로부터 분 리되는 대표적인 균종이라고 보고하였고, Seo 등(2014)도 묵 은지로부터 E. faecium $\mathrm{SH} 01$ 을 분리한 바 있는데, 이와 같이 이전의 연구에서 분리된 김치나 묵은지의 유산균들은 본 연구 결과에서도 일부 동일하였다. 숙성 전에는 L. mesenteroides가 우점종인 반면, 발효 후기에는 Lactobacillus 속이 주요 유산 균으로 분리된다고(Rhee 등, 2011) 알려졌는데, 본 연구에서 는 까나리 액젓을 첨가하여 발효시킨 묵은지를 제외한 시료 에서 L. mesenteroides가 발효 초기에서부터 오랜 기간 동안 유지되었는데, 이는 저장 온도 $\left(2^{\circ} \mathrm{C}\right)$ 가 낮았기 때문인 것으로 보여진다(data not shown). 따라서 김치 내 우점종 유산균의
종류는 김치의 원료와 제조 환경 및 발효 조건에 영향을 받는 것으로 추정된다.

유산균과 달리 효모는 김치 발효 후반에 나타나기 시작하 며, 펙틴 분해 효소를 분비함으로써 김치의 조직감을 악화시 키고 이취를 발생시키기 때문에 김치 발효에 유해한 미생물 로 간주되고 있다(Lee 등, 2018). 김치 내 효모수는 발효 초 기에서 중기까지는 원료로부터 유입되어 일정하게 유지되다 가 중기 이후부터 유산균수가 감소되기 시작하면서 점진적으 로 증가되어 김치 내에 알코올, 글리세롤, 비타민 및 방향성 물질을 생산함으로써 독특한 풍미를 제공할 뿐만 아니라, 발 효 후기에는 주로 산막효모가 증식함으로써 김치의 조직을 무르게 하는 연부 현상을 유발한다(Kang 등, 2019). 본 연구 의 시료로부터 분리된 유산균수도 담근 직후에는 $6.9 \pm 3.1$ $\times 10^{5}-7.0 \pm 1.1 \times 10^{6} \mathrm{CFU} / \mathrm{g}$ 정도에서 발효가 진행됨에 따라 서 서히 증가하기 시작하여 최대 균수는 발효 3-6개월에 이르렀 다가 그 이후에는 서서히 감소되어 9개월 발효시킨 묵은지 에서는 $8.8 \pm 1.9 \times 10^{6}-6.2 \pm 0.2 \times 10^{7} \mathrm{CFU} / \mathrm{g}$ 수준이었다. 하지만 효모는 발효 3 개월부터 검출되기 시작하였고, 9 개월된 묵은 지에선 $6.0 \pm 3.2 \times 10^{3}-1.3 \pm 0.3 \times 10^{5} \mathrm{CFU} / \mathrm{g}$ 으로 검출되었으므 로(Lim, 2020) 기존 연구와 비슷한 경향으로 나타났다. Kang 등(2019)은 배추김치로부터 Brettanomyces claussenii, Candida bogoriensis, Candida cacaoi, Candida guilliermondii, Citeromyces matritensis, Kluyveromyces vaeronae, $P$. membranefacience, Rhodotorula glutinis, Saccharomyces bayanus, S. cerevisiae, Saccharomyces pretoriensis, Saccharomyces italicus, Torulopsis salmanticensis 등이 분리되었고, Pichia kudriazevii, Pichia kluyveri, Kazachstania exigua, Kazachstania pseudohumilis, Kazachstania servazzii, Candida 
sake, Y. lipolytica 등 김치 표면에 피막을 형성하는 산막효모 들이 발효 후기에 분리되었다고 보고하였다. 본 연구에서도 이들 결과에서 분리된 효모와 일부 균종이 일치하였으며, 발 효 기간이 길어짐에 따라 묵은지의 조직감이 물러지고 이취 가 발생되었다(data not shown).

\section{젓갈 종류별 묵은지로부터 분리된 미생물의 $\mathrm{BA}$ 생성능} 묵은지로부터 분리된 미생물의 $\mathrm{BA}$ 생성능을 측정한 결과 는 Table 3 과 같다. L. mesenteroides subsp. mesenteroides CML01은 히스타민을 $562.3 \pm 13.6 \mathrm{mg} / \mathrm{L}$ 생성하였고, $L$. plantarum CML02로부터 카다베린 생성능(103.6 $\pm 1.2 \mathrm{mg} / \mathrm{L})$

Table 3. BA-forming abilities of lactic acid bacteria and yeast isolated from over-ripened kimchi prepared with different kinds of salted and fermented seafoods

\begin{tabular}{|c|c|c|c|c|c|}
\hline \multirow{2}{*}{ Source } & \multirow{2}{*}{ Strain } & \multicolumn{4}{|c|}{ BA-forming ability (mg/L) } \\
\hline & & Cadaverine & Histamine & Putrescine & Tyramine \\
\hline \multirow{3}{*}{$\begin{array}{l}\text { Over-ripened kimchi } \\
\text { prepared with } \\
\text { sun-dried salt }\end{array}$} & Leuconostoc mesenteroides subsp. mesenteroides CML01 & $\mathrm{ND}^{1)}$ & $562.3 \pm 13.6^{2)}$ & ND & ND \\
\hline & Lactobacillus plantarum CML02 & $103.6 \pm 1.2$ & ND & ND & ND \\
\hline & Saccharomyces cerevisiae CMY03 & ND & $107.2 \pm 16.8$ & ND & $34.7 \pm 5.5$ \\
\hline \multirow{7}{*}{$\begin{array}{l}\text { Over-ripened kimchi } \\
\text { prepared with } \\
\text { 'Kanari-aekjeot' }\end{array}$} & Lactobacillus brevis KML11 & $384.2 \pm 20.9$ & ND & ND & $411.4 \pm 30.9$ \\
\hline & Enterococcus faecium KML12 & ND & ND & ND & ND \\
\hline & Weissella confusa KML13 & ND & $115.7 \pm 13.0$ & ND & ND \\
\hline & Pediococcus pentosaceus KML14 & ND & $357.4 \pm 35.1$ & ND & ND \\
\hline & Enterococcus faecium KML15 & ND & $193.2 \pm 25.8$ & ND & $99.4 \pm 1.0$ \\
\hline & Zygosaccharomyces mellis KMY16 & $80.7 \pm 2.7$ & ND & ND & ND \\
\hline & Pichia fermentans KMY17 & ND & $147.6 \pm 5.4$ & ND & $99.3 \pm 11.0$ \\
\hline \multirow{9}{*}{$\begin{array}{l}\text { Over-ripened kimchi } \\
\text { prepared with } \\
\text { 'Myeolchi- } \\
\text { aekjeot' }\end{array}$} & Lactobacillus fermentum MML21 & ND & ND & ND & ND \\
\hline & Leuconostoc mesenteroides MML22 & ND & $287.4 \pm 24.0$ & $68.2 \pm 11.9$ & ND \\
\hline & Lactobacillus sakei MML23 & ND & ND & ND & ND \\
\hline & Lactobacillus brevis MML24 & ND & $112.3 \pm 6.7$ & $451.7 \pm 2.3$ & ND \\
\hline & Lactobacillus plantarum MML25 & ND & $494.2 \pm 5.1$ & ND & $84.2 \pm 3.5$ \\
\hline & Enterococcus faecalis MML26 & $231.5 \pm 5.2$ & ND & $55.9 \pm 14.9$ & ND \\
\hline & Saccharomyces cerevisiae MMY27 & ND & ND & $164.2 \pm 21.1$ & ND \\
\hline & Pichia membranefaciens MMY28 & $209.7 \pm 11.4$ & ND & ND & ND \\
\hline & Candida versatilis MMY29 & ND & $56.9 \pm 2.9$ & ND & $76.5 \pm 2.2$ \\
\hline \multirow{7}{*}{$\begin{array}{l}\text { Over-ripened kimchi } \\
\text { prepared with } \\
\text { 'Saeu-jeot' }\end{array}$} & Leuconostoc mesenteroides SML31 & ND & $299.7 \pm 24.1$ & ND & ND \\
\hline & Lactobacillus brevis SML32 & $205.8 \pm 32.5$ & ND & ND & ND \\
\hline & Lactobacillus plantarum SML33 & $318.2 \pm 14.5$ & ND & ND & ND \\
\hline & Pediococcus pentosaceus SML34 & ND & ND & ND & ND \\
\hline & Lactobacillus sakei SML35 & ND & ND & $347.2 \pm 5.2$ & $491.2 \pm 40.3$ \\
\hline & Debaryomyces hansenii SMY36 & $66.7 \pm 6.0$ & ND & ND & ND \\
\hline & Pichia membranefaciens SMY37 & ND & ND & ND & $47.1 \pm 3.4$ \\
\hline
\end{tabular}

${ }^{1)} \mathrm{ND}$, not detected.

${ }^{2)}$ All values are the mean $\pm \mathrm{SD}$ of the three replicates. 
이 확인되었다. L. brevis KML11은 다량의 카다베린과 티라민 을 생성하였고, $W$. confuse KML13과 P. pentosaceus KML14 로부터는 히스타민 생성능이 확인되었으며, E. faecium KML15는 히스타민뿐만 아니라 티라민도 생성하였다. $L$. mesenteroides MML22와 L. brevis MML24는 히스타민과 푸트레신을 생성하였다. 게다가 L. plantarum MML25는 다 량의 히스타민과 티라민, E. faecalis MML26에 의해선 카다 베린과 푸트레신의 생성능이 확인되었다. L. mesenteroides SML31은 히스타민, L. brevis SML32와 L. plantarum SML33은 카다베린을 생성하였고, L. sakei SML35는 푸트레 신과 티라민을 생성하였다.

한편, S. cerevisiae CMY03은 히스타민(107.2 $\pm 16.8 \mathrm{mg} / \mathrm{L})$ 을 생성하였고 Z. mellis KMY16은 카다베린(80.7 \pm 2.7 $\mathrm{mg} / \mathrm{L})$, P. fermentans KMY17은 히스타민(147.6 $\pm 5.4 \mathrm{mg} / \mathrm{L})$ 과 티라민(99.3 $\pm 11.0 \mathrm{mg} / \mathrm{L}), S$. cerevisiae MMY27은 푸트레신 $(164.2 \pm 21.1 \mathrm{mg} / \mathrm{L})$ 을 생성하였다. P. membranefaciens MMY28 은 카다베린(209.7 $\pm 11.4 \mathrm{mg} / \mathrm{L})$, C. versatilis MMY29는 히 스타민 $(56.9 \pm 2.9 \mathrm{mg} / \mathrm{L})$ 과 티라민 $(76.5 \pm 2.2 \mathrm{mg} / \mathrm{L})$ 을 생성하 였다. D. hansenii SMY36은 카다베린 $(66.7 \pm 6.0 \mathrm{mg} / \mathrm{L}), P$. membranefaciens SMY37은 티라민 $(47.1 \pm 3.4 \mathrm{mg} / \mathrm{L})$ 을 생성 하였다.

이상의 결과에서 볼 때 젓갈 종류별 묵은지에서 분리된 유 산균과 효모의 균주에 따라 생성되는 $\mathrm{BA}$ 의 종류와 생성량에 는 유의한 차이가 있음을 알 수 있었다.

천일염보다는 액젓이나 젓갈을 첨가한 묵은지로부터 다양 한 종류의 BA 생성 유산균 및 효모가 분리되었는데, 이는 액 젓이나 젓갈 자체에 함유된 $\mathrm{BA}$ 생성균에 의한 것으로 추정 된다. 본 연구에서 사용된 까나리 액젓(푸트레신: $5.4 \pm 1.2$ $\mathrm{mg} / \mathrm{kg}$, 카다베린: $192.4 \pm 10.1 \mathrm{mg} / \mathrm{kg}$, 히스타민: $316.7 \pm 5.8$ $\mathrm{mg} / \mathrm{kg}$, 티라민: $12.4 \pm 1.7 \mathrm{mg} / \mathrm{kg}$ ), 멸치 액젓(푸트레신: $331.9 \pm$ $20.4 \mathrm{mg} / \mathrm{kg}$, 카다베린: $221.6 \pm 16.9 \mathrm{mg} / \mathrm{kg}$, 히스타민: $201.3 \pm$ $0.9 \mathrm{mg} / \mathrm{kg}$, 티라민: $8.9 \pm 0.2 \mathrm{mg} / \mathrm{kg}$ ) 및 새우젓갈(카다베린 및 히스타민: 불검출, 푸트레신: $152.3 \pm 13.7 \mathrm{mg} / \mathrm{kg}$, 티라민: $342.1 \pm$ $22.4 \mathrm{mg} / \mathrm{kg}$ )로부터 BA가 검출(data not shown)되었으므로 이들 수산 발효 식품 내에는 BA 생성능이 있는 미생물이 존 재하였으며, 결국 김치와 묵은지의 $\mathrm{BA}$ 함량에도 영향을 미 친 것으로 판단된다. 본 결과와 유사하게 파와 갓 김치로부터 검출된 $\mathrm{BA}$ 는 액젓으로부터 유래되는 것으로 보고된 바 있고 (Lee 등, 2019), Tsai 등(2005)도 배추김치로부터 검출된 과 량의 히스타민은 액젓의 첨가에 따른 것이라고 밝혔다.

Jin 등(2019)은 깍두기와 총각김치로부터 분리된 티라민을 생성하는 일부 유산균 중 김치의 숙성이 진행되는 동안 티라 민의 양을 증가시키는 균주는 L. brevis로 동정되었는데, 본 연구에서도 천일염을 제외한 액젓과 젓갈을 첨가하여 제조한
묵은지로부터 L. brevis KML11, MML24 및 SML32가 분리 되었으며, 이들은 티라민을 비롯하여 카다베린, 히스타민 및 푸트레신을 생성하였다. 배추김치에서 분리된 L. mesenteroides는 티라민을 생성한 반면(Kim과 Kim, 2014) L. mesenteroides MML22는 히스타민과 푸트레신을, SML31은 히스 타민을 생성하였다. 와인으로부터 분리된 L. plantarum은 티 라민을 생성한 것으로 보고된 바 있는데(Arena 등, 2007), $L$. plantarum CML02와 SML33은 카다베린, MML25는 히스타 민과 티라민을 생성하였다. 이와는 달리 깍두기와 총각김치 로부터 분리된 L. mesenteroides, Lactobacillus pentosus 및 L. plantarum은 $\mathrm{BA}$ 를 생성하지 않는 것으로 확인되었는데 (Jin 등, 2019), 본 연구 결과에서는 이들과 동일한 균종들로 부터 $\mathrm{BA}$ 생성능이 확인되어 상반되는 결과를 얻었다. 또한, 배추김치의 우점종 유산균인 L. brevis, L. plantarum, $L$. mesenteroides, P. pentosaceus도 $\mathrm{BA}$ 를 생산하지 않는 것으 로 보고된 바 있어, 유산균의 BA 생성능은 균종보다는 균주 에 의존하는 것을 알 수 있었다(Mah 등, 2019).

Baumlisberger 등(2015)은 레드 와인으로부터 분리된 Dekkera bruxellensis는 다양한 종류의 $\mathrm{BA}$ 를 생산하였고, 토양으로부 터 분리된 $D$. hansenii $\mathrm{H1} / 2-72$ 는 푸트레신, 히스타민 및 티 라민, H199는 히스타민과 티라민, H524와 H525는 BA를 생 성하지 않는 것으로 확인되어 균주에 따라 생성하는 $\mathrm{BA}$ 의 종류가 다르다고 밝혔다. 또한, 와인으로부터 분리된 $P$. membranefaciens $\mathrm{H} 227$ 은 티라민, Schizosaccharomyces pombe K81은 푸트레신, 티라민, 에틸아민, Zygosaccharomyces rouxii는 티라민과 에틸아민을 생성하는 것으로 확 인되어 발효 식품 제조에 활용되는 효모에 의해서도 다양한 $\mathrm{BA}$ 가 생성된다고 보고하였다. 본 연구에서의 P. membranefaciens MMY29는 히스타민과 티라민, SMY37은 티라민 을 생산하여 Bäumlisberger 등(2015)의 결과와는 부분적으로 일치하였다. Caruso 등(2002)은 포도와 와인으로부터 분리된 Brettanomyces bruxellensis에 의해 총 BA 함량 $(15 \mathrm{mg} / \mathrm{L})$ 이 가장 높았고, 그 다음으로는 S. cerevisiae가 생산한 총 $\mathrm{BA}$ 함량 $(12.14 \mathrm{mg} / \mathrm{L})$ 이 가장 많은 것으로 나타났다. 특히 $S$. cerevisiae로 발효시킨 와인에는 에틸아민(2.3-16 mg/L), 아 그마틴(3.1-7.5 mg/L)이 가장 높게 측정되었다고 하여 본 연 구의 S. cerevisiae CMY03(히스타민) 및 MMY28(카다베린) 과는 다른 종류의 $\mathrm{BA}$ 를 생산하는 것으로 확인되었다. Qi 등 (2014)은 히스타민, 티라민, 카다베린, 스페르미딘 등의 함량 은 C. versatilis와 Z. rouxii 등의 효모에 의해 증가되었고, 간 장 내에서 Z. rouxii는 $121.71 \mathrm{mg} / \mathrm{kg}, C$. versatilis는 69.96 $\mathrm{mg} / \mathrm{kg}$ 생산하였으며, 효모의 아미노산 탈탄산 효소가 아미 노산으로부터 $\mathrm{BA}$ 를 생산하고 발효 기간이 길어질수록 $\mathrm{BA}$ 량 은 증가된다고 하였다 
유산균은 영양분이 고갈된 상태에서도 에너지 획득 능력 과 강한 생존력을 발휘하여 열악한 조건에서 상당 기간 견딜 수 있는 적응력을 가지고 있다(Barbieri 등, 2019). 특히 야생 형 유산균은 낮은 $\mathrm{pH}$ 에 대응할 수 있는 메커니즘을 활성화하 여 산에 대한 스트레스에 저항할 수 있다. 스트레스에 노출된 유산균은 아미노산 탈탄산화 시스템의 발현과 활성화를 통해 에너지 고갈 상황에서도 적응력을 높이고, 이로 인하여 $\mathrm{BA}$ 생성이 가능해진다(Lucas 등, 2007). BA 생성과 관련된 탈탄 산 효소 유전자의 존재는 균종보다는 균주에 의존하고, 열악 한 조건 하에서의 생존과 적응을 위한 메커니즘의 일부분으 로써 균주들 사이에 유전자 수평 전달도 가능하다(Barbieri 등, 2019). 이와 같은 유산균의 아미노산 탈탄산화 메커니즘 으로 인해 김치의 발효가 진행됨에 따라 유산균이 생성한 유 기산으로 $\mathrm{pH}$ 가 낮아져도 $\mathrm{BA}$ 생성량은 유의하게 증가될 수 있을 것으로 판단된다.

\section{젓갈 종류별 묵은지로부터 분리된 미생물의 $\mathrm{BA}$ 분해능}

묵은지로부터 분리된 미생물의 $\mathrm{BA}$ 분해능을 측정한 결과 는 Table 4 와 같다. L. mesenteroides subsp. mesenteroides $\mathrm{CML} 01$ 은 카다베린 분해능 $(6.5 \pm 0.9 \%)$ 을 나타내었고, $E$. faecium KML12로부터는 히스타민(41.7 $\pm 2.2 \%$ )과 티라민 (25.3 $\pm 0.4 \%)$ 의 분해능이 확인되었다. L. fermentum MML21 에 의해선 카다베린(24.2 $\pm 0.9 \%)$, L. sakei MML23은 푸트레 신(31.2 $\pm 4.8 \%)$ 과 티라민(19.7 $\pm 4.1 \%)$, E. faecalis MML26에

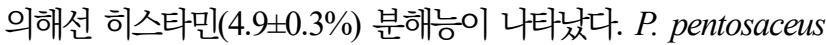
SML34는 푸트레신을 $25.7 \pm 0.9 \%$ 분해시키는 것으로 확인되 었다. 반면, 시료로부터 분리된 모든 효모에 의해서는 $\mathrm{BA}$ 분 해능이 확인되지 않았다.

본 연구 결과에서 보듯이 균주에 따라 특정 $\mathrm{BA}$ 을 생성한 반면, 또 다른 BA에 대해선 분해능을 나타내기도 하였다. Jin 등(2019)은 발효가 진행될수록 깍두기와 총각김치 내 티라민 과 히스타민 함량이 서서히 감소되었는데 이는 BA 분해능이 있는 유산균에 의한 것이라고 추정하였다. Kim 등(2017)도 히스타민 분해능이 있는 L. sakei, L. plantarum, Leuconostoc carnosus 및 L. mesenteroides로 접종한 배추김치 내에 히스 타민 함량은 대조구에 비해 유의하게 감소되었음을 보고하였 다. Urs 등(2019)에 의해 L. plantarum은 히스타민(100\%), 티라민(100\%), 카다베린(28\%) 및 푸트레신(67.8\%)을 분해 한 것으로 확인되었다. 이와 유사하게 본 연구의 결과에서도 L. mesenteroides subsp. mesenteroides CML01(카다베린), E. faecium KML12(히스타민, 티라민), L. fermentum MML21 (카다베린), L. sakei MML23(푸트레신, 티라민), E. faecalis MML26(히스타민), P. pentosaceus SML34(푸트레신)로부터 $\mathrm{BA}$ 분해능이 확인되었는데, 세균의 $\mathrm{BA}$ 분해능은 아민 산화 효소(amine oxidase)에 의해 산화적 탈아미노화 반응을 유도 함으로써 나타난다고 알려져 있다(Tabanellin 등, 2014).

전보 $(\mathrm{Lim}, 2020)$ 결과, 천일염으로 담근 김치에서부터 카다 베린 $(0-105.16 \pm 5.07 \mathrm{mg} / \mathrm{kg})$ 과 히스타민 $(0-326.82 \pm 0.75 \mathrm{mg} / \mathrm{kg})$ 의 함량은 발효가 진행될수록 증가되었는데 L. mesenteroides subsp. mesenteroides CML01, L. plantarum CML02 및 $S$. cerevisiae $\mathrm{CMY03}$ 의 영향인 것으로 추정된다. 한편, $L$. mesenteroides subsp. mesenteroides CML01은 카다베린 분 해능이 확인되었으나, 활성이 낮아 묵은지 카다베린 함량을 유의하게 낮추지는 못한 것으로 판단된다.

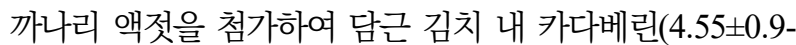
$440.96 \pm 2.97 \mathrm{mg} / \mathrm{kg}$ )의 함량은 발효가 진행될수록 점진적으 로 증가되었는데, 이는 L. brevis KML11과 Z. mellis KMY16 의 영향으로 추정된다. 히스타민 $(8.52 \pm 0.15-274.52 \pm 6.37 \mathrm{mg} / \mathrm{kg})$ 의 함량은 P. pentosaceus KML14, W. confusa KML13, E. faecium KML15 및 P. fermentans KMY17의 영향인 것으로 보여지며, 히스타민의 함량은 6 개월 이후부터는 오히려 감소 되었는데, 이는 E. faecium KML12의 분해능의 영향인 것으 로 추정된다. 한편, 시료 내 티라민 $(0-368.05 \pm 0.99 \mathrm{mg} / \mathrm{kg})$ 은 L. brevis KML11과 E. faecium KML15 및 P. fermentans $\mathrm{KMY} 17$ 의 영향인 것으로 간주되며, 티라민의 함량은 9 개월 이후부터 일정한 수준이 유지되었는데, 이는 E. faecium $\mathrm{KML} 12$ 의 분해능 및 생성균의 사멸에 의한 것으로 추정된다.

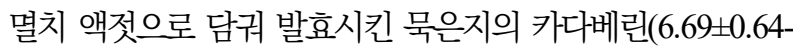
$185.72 \pm 1.66 \mathrm{mg} / \mathrm{kg}$ ) 함량은 E. faecalis MML26, P. membranefaciens MMY28의 영향인 것으로 간주되며, 발효 후기 로 갈수록 L. fermentum MML21의 분해능에 의해 카다베린 의 함량은 크게 증가하지 않은 것으로 추정된다. 푸트레신 (9.42 $\pm 1.11-310.54 \pm 3.00 \mathrm{mg} / \mathrm{kg})$ 의 함량은 L. mesenteroides MML22, L. brevis MML24, E. faecalis MML26 및 $S$. cerevisiae MMY27의 영향인 것으로 보여지며, 발효 후기에 그 함량이 크게 증가되지 않았던 것은 L. sakei MML23의 분 해능과 생성균의 사멸에 기인하는 것으로 간주된다. 티라민 $(0-93.89 \pm 2.26 \mathrm{mg} / \mathrm{kg})$ 의 함량은 L. plantarum MML25 및 $C$. versatilis MMY29에 기인하며, 9개월 이후에 일정한 수준으 로 유지된 것은 L. sakei 23 의 분해능 및 L. plantarum MML25의 사멸에 의한 것으로 보여진다. 반면, 히스타민 $(5.61 \pm 1.80-815.26 \pm 5.5 \mathrm{mg} / \mathrm{kg})$ 의 함량은 L. mesenteroides MML22, L. brevis MML24, L. plantarum MML25 및 $C$. versatilis MMY29에 의하며, E. faecalis MML26으로부터 분해능이 확인되었으나, 활성이 낮아 함량 감소에는 큰 영향 을 미치지 않았던 것으로 판단된다.

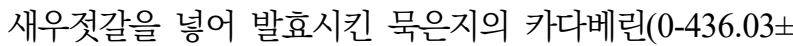
$8.4 \mathrm{mg} / \mathrm{kg}$ )은 L. brevis SML32와 L. plantarum SML33 및 
Table 4. BA-degrading abilities of lactic acid bacteria and yeast isolated from over-ripened kimchi prepared with different kinds of salted and fermented seafoods

\begin{tabular}{|c|c|c|c|c|c|}
\hline \multirow{2}{*}{ Source } & \multirow{2}{*}{ Strain } & \multicolumn{4}{|c|}{ BA-degrading ability (\%) } \\
\hline & & Cadaverine & Histamine & Putrescine & Tyramine \\
\hline \multirow{3}{*}{$\begin{array}{l}\text { Over-ripened kimchi } \\
\text { prepared with } \\
\text { sun-dried salt }\end{array}$} & Leuconostoc mesenteroides subsp. mesenteroides CML01 & $6.5 \pm 0.9^{1)}$ & ND & ND & ND \\
\hline & Lactobacillus plantarum CML02 & $\mathrm{ND}^{2)}$ & ND & ND & ND \\
\hline & Saccharomyces cerevisiae CMY03 & ND & ND & ND & ND \\
\hline \multirow{7}{*}{$\begin{array}{l}\text { Over-ripened kimchi } \\
\text { prepared with } \\
\text { 'Kanari-aekjeot' }\end{array}$} & Lactobacillus brevis KML11 & ND & ND & ND & ND \\
\hline & Enterococcus faecium KML12 & ND & $41.7 \pm 2.2$ & ND & $25.3 \pm 0.4$ \\
\hline & Weissella confusa KML13 & ND & ND & ND & ND \\
\hline & Pediococcus pentosaceus KML14 & ND & ND & ND & ND \\
\hline & Enterococcus faecium KML15 & ND & ND & ND & ND \\
\hline & Zygosaccharomyces mellis KMY16 & ND & ND & ND & ND \\
\hline & Pichia fermentans KMY17 & ND & ND & ND & ND \\
\hline \multirow{9}{*}{$\begin{array}{l}\text { Over-ripened kimchi } \\
\text { prepared with } \\
\text { 'Myeolchi- } \\
\text { aekjeot' }\end{array}$} & Lactobacillus fermentum MML21 & $24.2 \pm 0.9$ & ND & ND & ND \\
\hline & Leuconostoc mesenteroides MML22 & ND & ND & ND & ND \\
\hline & Lactobacillus sakei MML23 & ND & ND & $31.2 \pm 4.8$ & $19.7 \pm 4.1$ \\
\hline & Lactobacillus brevis MML24 & ND & ND & ND & ND \\
\hline & Lactobacillus plantarum MML25 & ND & ND & ND & ND \\
\hline & Enterococcus faecalis MML26 & ND & $4.9 \pm 0.3$ & ND & ND \\
\hline & Saccharomyces cerevisiae MMY27 & ND & ND & ND & $\mathrm{ND}$ \\
\hline & Pichia membranefaciens MMY28 & ND & ND & ND & ND \\
\hline & Candida versatilis MMY29 & ND & ND & ND & ND \\
\hline \multirow{7}{*}{$\begin{array}{l}\text { Over-ripened kimchi } \\
\text { prepared with } \\
\text { 'Saeu-jeot' }\end{array}$} & Leuconostoc mesenteroides SML31 & ND & ND & ND & ND \\
\hline & Lactobacillus brevis SML32 & ND & ND & ND & ND \\
\hline & Lactobacillus plantarum SML33 & ND & ND & ND & ND \\
\hline & Pediococcus pentosaceus SML34 & ND & ND & $25.7 \pm 0.9$ & ND \\
\hline & Lactobacillus sakei SML35 & ND & ND & ND & ND \\
\hline & Debaryomyces hansenii SMY36 & ND & ND & ND & ND \\
\hline & Pichia membranefaciens SMY37 & ND & ND & ND & ND \\
\hline
\end{tabular}

${ }^{1)}$ All values are the mean \pm SD of the three replicates.

${ }^{2)}$ Not detected.

D. hansenii SMY36에 기인하며, 히스타민(0-419.16 \pm 1.11 $\mathrm{mg} / \mathrm{kg}$ )의 함량은 L. mesenteroides SML31의 영향이고, 푸트 레신(4.87 $\pm 0.37-180.21 \pm 7.67 \mathrm{mg} / \mathrm{kg})$ 과 티라민(10.52 \pm 0.32 $390.36 \pm 0.51 \mathrm{mg} / \mathrm{kg}$ )은 모두 L. sakei SML35에 의한 것으로 발효 12 개월까지 카다베린, 히스타민 및 티라민의 함량은 꾸 준하게 증가되었다. 하지만 푸트레신의 함량은 P. pentosaceus
SML34의 분해능에 의해 발효 후기로 갈수록 생성량이 크게 증가되지 않았던 것으로 추정된다.

이상의 결과, 발효 채소류의 우점종인 유산균과 효모의 균 주에 따라 BA 생성량이 상이하다는 것을 알 수 있었으며, 일 부의 발효 미생물에 의해선 $\mathrm{BA}$ 분해능이 확인되었으므로 발 효 식품 제조에 이용하는 미생물의 $\mathrm{BA}$ 생성 여부 확인이 반 
드시 필요할 것으로 사료된다.

\section{$\mathrm{BA}$ 분해능을 나타낸 분리 균주의 프로바이오틱 활성}

$\mathrm{BA}$ 를 생성하지 않고 $\mathrm{BA}$ 분해능이 있는 E. faecium KML12, L. fermentum MML21, L. sakei MML23 및 $P$. pentosaceus SML34를 선발하여 프로바이오틱 균주의 가능 성을 평가하기 위해 인공 소화액에 대한 저항성과 $\mathrm{CaCo}-2$ 세 포에 대한 부착능을 조사한 결과는 Fig. 1과 같다. E. faecium $\mathrm{KML} 12$ 는 $\mathrm{pH} 2.0$ 의 인공 위액 하에서의 생존율 $0.5 \pm 0.03 \%$, $1 \%$ bile salts 하에서는 $17.5 \pm 4.7 \%$ 생존하였고 상피세포에 대한 부착율은 $4.7 \pm 1.1 \%$ 이었다. L. fermentum MML 21 의 인 공 위액과 담즙액 하에서의 생존율은 각각 $0.06 \pm 0.01 \%$ 와 $32.4 \pm 2.9 \%$ 이었으며, 상피세포에 대한 부착율은 $27.2 \pm 3.9 \%$ 로 나타났다. L. sakei MML23의 인공 위액과 담즙액 하에서 의 생존율은 각각 $23.9 \pm 3.4 \%$ 와 $52.8 \pm 3.1 \%$ 이었고, 상피세포 에 대한 부착율은 $7.2 \pm 0.9 \%$ 로 나타났다. P. pentosaceus SML34의 인공 위액과 담즙액에서의 생존율은 각각 $1.9 \pm 0.3 \%$ 와 $25.8 \pm 5.0 \%$ 로 나타났으며, 상피세포에 대한 부착율은 $18.7 \pm 3.7 \%$ 로 측정되었다. 이상의 결과, 인공 소화액에 대한 저항성과 상피세포에 대한 부착율은 균종에 따라 유의한 차 이가 있었으며, 인공 위액과 담즙액에 대한 저항성은 L. sakei MML23이 가장 높았고, 상피세포에 대한 부착율은 $L$. fermentum MML21이 가장 높은 것으로 나타났다.

Lertworapreecha 등(2011)은 총 60균주의 E. faecium 중 15 균주는 산에 대한 저항성이 확인되었고, 그 중에서 $\mathrm{EFMC21,} \mathrm{EFMD30,} \mathrm{EFMI47} \mathrm{및} \mathrm{EFMI49는} \mathrm{담즙에} \mathrm{노출되}$ 었을 때 생존율이 높았으며, 장관 점막에 대한 부착율도 높았

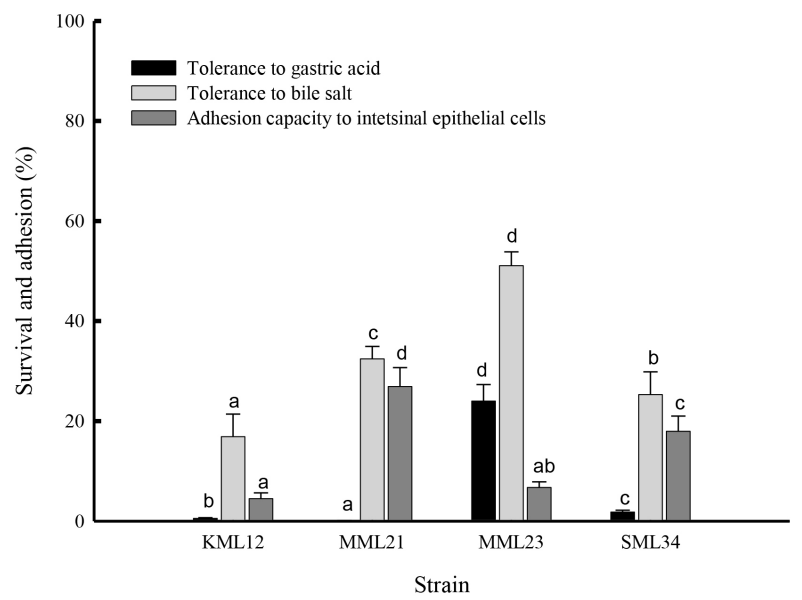

Fig. 1. Tolerance to gastric acid and bile salt and adhesion capacity to intestinal epithelial cells of BA-degrading lactic acid bacteria isolated from over-ripened kimchi prepared with different kinds of salted and fermented seafoods.
다고 보고하였는데 E. faecium KML12는 산에 대한 저항성 은 이들보다 다소 낮았다. Allameh 등(2013)에 의하면 $L$. fermentum-3은 $\mathrm{pH}$ 3-8 및 0.3\% 담즙염 하에서 증식 가능하 였고, 또한 L. fermentum BIF-19는 강한 세포 표면 소수성에 따라 Caco-2 세포에 양호한 부착력( $8.78 \pm 0.36 \%)$ 을 나타내었 으며(Panicker 등, 2018), L. fermentum MML21도 담즙산에 대한 내성과 우수한 부착율을 나타내었다. L. sakei $\mathrm{J} 4$ 는 인공 위액에 대한 생존율은 $24.3 \pm 3.0 \%$, 담즙산에 대한 생존율은 $25.8 \pm 0.4 \%$ 로 다른 균주에 비해 상대적으로 높은 생존율을 나타내었고(Park 등, 2012), L. sakei CH8은 장관 상피 세포 와 2시간 혼합 배양 후 높은 부착률을 보여주었다(Song 등, 2015). P. pentosaceus MZF16은 위액과 담즙염에 대한 스트 레스에 높은 저항성을 나타내었고, 소수성 표면 특성을 나타 내어 장관 Caco-2/TC7 세포에 대해 높은 부착력을 나타내었 다고 하여(Zommiti 등, 2018) 본 연구 결과와는 다소 차이가 있었다.

E. faecium KML12, L. fermentum MML21, L. sakei MML23 및 P. pentosaceus SML34의 항생제에 대한 감수성 을 측정한 결과는 Table 5 와 같다. E. faecium KML12는 암 피실린, 에리스로마이신 및 반코마이신에 대한 감수성이 높 게 나타났으며, 카나마이신과 테트라사이클린에 대해 저항성 이 큰 것으로 나타났다. L. fermentum MML21은 페니실린에 대한 감수성이 높았던 반면, 스트렙토마이신에 대한 저항성 이 크게 나타났다. L. sakei MML23은 에리스로마이신과 테 트라사이클린에 대한 감수성이 높았고, 암피실린과 페니실린 에 대한 저항성이 큰 것으로 확인되었다. P. pentosaceus SML34는 암피실린과 카나마이신에 대한 감수성이 높았고, 페니실린에 대한 저항성이 크게 나타났다. E. faecium EFMC21, EFMD25, EFMI47 및 EFMI49는 박테리오신을 생산하였으며, 아목시실린/클라불란산, 시프로플록사신, 젠타 마이신, 트리메소프림/설파메톡사졸, 반코마이신에 대해 감 수성이 높았던 반면, 세포탁심, 에리스로마이신 및 테트라사 이클린에 대해 저항성이 높았다고 하여(Lertworapreecha 등, 2011) E. faecium KML12와는 일부 항생제에 대해 비슷한 경향의 감수성을 나타내었다. L. fermentum-3은 스트렙토마 이신, 젠타마이신 및 카나마이신에 대해 저항성이 강하였고, 테트라사이클린에 대해선 중간 정도의 수준이었으며, 클로람 페니콜, 아목시실린, 암피실린에 대해서 감수성이 강한 것으 로 나타나 프로바이오틱 균주로서 적합하다고 하였다 (Allameh 등, 2013). L. sakei GMK01은 암피실린, 페니실린, 클록사실린, 클린다마이신, 클로람페니콜, 에리스로마이신, 젠타마이신, 카나마이신, 스트렙토마이신 등에 대해선 감수 성이 높았던 반면, 옥사실린, 바시트라신, 반코마이신, 세픽 심, 독시사이클린, 테트라사이클린 등에 대해 저항하였다 
Table 5. Antibiotic susceptibility of BA-degrading lactic acid bacteria isolated from over-ripened kimchi prepared with different kinds of salted and fermented seafoods

\begin{tabular}{cccccccc}
\hline \multirow{2}{*}{ Strain } & \multicolumn{7}{c}{ Minimal inhibitory concentration $(\mu \mathrm{g} / \mathrm{mL})$} \\
\cline { 2 - 7 } & Ampicillin & Erythromycin & Kanamycin & Penicillin & Streptomycin & Tetracycline & Vancomycin \\
\hline KML12 & 8 & 4 & 64 & 32 & 16 & 64 & 4 \\
MML21 & 32 & 16 & 32 & 4 & 64 & 32 & 16 \\
MML23 & 128 & 8 & 32 & 512 & 16 & 4 & 16 \\
SML34 & 4 & 32 & 4 & 128 & 32 & 16 & 64 \\
\hline
\end{tabular}

(Khiralla, 2015). P. pentosaceus MZF16 균주는 젠타마이신, 클로람페니콜 및 반코마이신에 대해선 저항성이 높았으나, 오 플로사신, 암피실린, 에리스로마이신, 스트렙토마이신 및 테 트라사이클린에 대한 감수성이 높았다고 하였는데(Zommiti 등, 2018), 본 연구의 이들과 동일한 균종과 비교했을 때 균 주에 따라 항생제의 감수성에 다소 차이가 있음을 알 수 있었 다.

한편, 본 연구의 묵은지로부터 분리된 BA 생성 유산균과 효모에 대한 E. faecium KML12, L. fermentum MML21, L. sakei MML23 및 P. pentosaceus SML34가 생산한 박테리오 신 용액의 항균 활성을 측정한 결과는 Table 5 와 같다. $E$. faecium KML12와 L. fermentum MML21이 생산한 박테리 오신 용액은 BA 생성균에 대해서 항균 활성을 나타내지 않 았지만, L. sakei MML23의 박테리오신은 E. faecium $\mathrm{KML} 15(2,560 \mathrm{AU} / \mathrm{mL})$ 와 $S$. cerevisiae $\mathrm{MMY} 28(320 \mathrm{AU} / \mathrm{mL})$ 에 대해 항균 활성을 나타내었으며, P. pentosaceus SML34 의 박테리오신도 L. brevis MML24(640 AU/mL)에 대해 항 균 활성을 나타내었다. 게다가 L. sakei MML 23이 생산한 박 테리오신 용액 $(100 \mathrm{AU} / \mathrm{mL})$ 을 처리한 경우 E. faecium KML15가 생산한 히스타민의 양을 $44.7 \pm 4.8 \%$ 와 S. cerevisiae $\mathrm{MMY} 28$ 이 생산한 카다베린을 $6.9 \pm 1.2 \%$ 감소시켰다. 또한 P. pentosaceus SML34가 생산한 박테리오신 용액은 L. brevis MML24의 히스타민(8.1 $\pm 0.5 \%)$ 과 푸트레신(10.7 $\pm 3.9 \%)$ 생성 량을 감소시키는 효과를 나타내었다. 본 연구의 결과, 유산균 의 균종에 따라 박테리오신의 항균 활성과 항균 스펙트럼에 상당한 차이가 있었으며, 항균 활성을 나타낸 박테리오신은 지시 균주의 증식 억제뿐만 아니라, 이들의 BA 생성량 감소 에도 효과적이었음을 확인하였다. L. fermentum-3은 어류 병 원균에 대한 강한 항균 활성을 나타내었으나(Allameh 등, 2013), L. fermentum BIF-19는 박테리오신을 생산하지 않은 것으로 나타났다(Panicker 등, 2018). L. sakei J4는 식중독균 에 대한 높은 항균력을 나타내었고(Park 등, 2012), P. pentosaceus MZF16은 박테리오신을 생산하여 Listeria 속에 대한 항균 활성이 확인되었다고 하여(Zommiti 등, 2018) 균
종에 따라 박테리오신 활성과 항균 스펙트럼은 상이하였다. 기존 연구 결과의 동일한 균종과는 프로바이오틱 활성에 다 소 차이가 있었으나, L. sakei MML23 및 P. pentosaceus SML34는 위액에 대한 내성과 담즙산에 대한 높은 생존율 및 일부 항생제에 대한 감수성뿐만 아니라, BA 생성균에 대한 박테리오신 활성도 확인되었으므로 프로바이오틱 균주로서 적합하다고 판단된다. Nisin을 생산하는 Lactococcus lactis 는 Streptococcus thermophilus와 E. faecalis의 BA 생산을 유 의하게 억제하였으므로 박테리오신을 생산하는 유산균을 활 용하는 방법이 BA 저감화에 효과적이라고 보고된 바 있다 (Tabanelli 등, 2014). BA 분해능과 항균 물질 생산능이 있는 L. sakei MML23 및 P. pentosaceus SML34 등을 발효 식품 제조용 스타터로 이용한다면 발효 및 저장 과정 중 생성된 $\mathrm{BA}$ 으로 인한 독성 위험을 낮출 수 있을 것으로 판단된다.

삶의 질이 향상됨에 따라 식품에 대한 소비자의 인식이 점 차 변화되면서 화학적으로 합성된 식품첨가물에 대한 거부감 이 강해지는 반면, 중독 위험이 없고 안전하면서 다양한 생리 활성을 가진 천연물이나 생물학적 물질을 이용한 식품을 선 호하고 있다. Generally recognized as safe(GRAS) 물질로서 무독성이 입증된 안전성과 건강에 유용한 생리활성뿐만 아니 라, 항균 물질 생산에 따른 품질 향상 등의 기능을 발휘할 수 있는 프로바이오틱 균주의 활용 가치가 높이 평가되고 있다 (Liu 등, 2017). BA 분해능이 있는 균주를 발효 스타터로 이 용함으로써 독성 물질 축적을 억제시키고, 박테리오신, 세포 외 다당류, 비타민 및 공액 리놀레산 등의 유용한 성분 공급 뿐만 아니라, 장 운동성과 흡착, 장내 세균총의 균형, 염증 감 소 및 면역 시스템 조절 등의 건강 기능 향상에 도움을 주는 프로바이오틱 활성을 보유하고 있다면 숙주의 건강에도 도움 을 줄 수 있는 기능성 식품 제조가 가능해질 것이다(Cousin 등, 2011; Li와 Cao, 2010). 하지만 인공 소화액에 대한 저항 성, 상피세포에 대한 부착능 및 항균물질 생산능 등 프로바이 오틱 균주로서 기본적인 조건을 갖추었다고 할지라도 $\mathrm{BA}$ 와 같은 독성 물질을 생성하지 않아야만 안전하게 이용할 수 있 으므로 발효 식품 제조에 이용하기 전에 아미노산 탈탄산 효 
소 생성능을 반드시 확인해야 할 것이다.

결론적으로 다양한 발효 식품을 안전하게 제조하기 위해 선 BA 생성능이 없고 분해능이 있는 발효 스타터 이용과 식 품의 제조 및 저장 과정 중에 $\mathrm{BA}$ 의 생성 여부 확인을 위한 모니터링을 통해 철저히 관리되어야 한다. 또한, $\mathrm{BA}$ 생성균 의 오염을 막을 수 있도록 최적의 제조 환경을 설정하고, 식품 의 물성과 영양가에 악영향을 미치지 않는 제조 공정 기술을 적용하거나, 아민으로 전환되지 않는 새로운 원료를 개발하는 등 소비자가 안심하고 섭취할 수 있는 안전한 발효 식품 제조 에 관한 연구는 앞으로도 계속 활발하게 이루어져야 할 것이다.

\section{요 약}

본 연구에서는 다양한 젓갈로 제조한 묵은지로부터 분리 된 유산균과 효모의 BA 생성 및 분해능을 측정하고 분해능 이 있는 균주의 프로바이오틱 활성을 조사하였다. 천일염보 다는 액젓이나 젓갈을 첨가하여 제조한 묵은지 내에서 $\mathrm{BA}$ 생성 유산균과 효모수가 유의하게 많았고, 이들의 BA 생성 능은 균주 의존형이었다. Leuconostoc mesenteroides subsp. mesenteroides CML01, Enterococcus faecium KML12, Lactobacillus fermentum MML21, Lactobacillus sakei MML23, Enterococcus faecalis MML26 및 Pediococcus pentosaceus SML34로부터 BA에 대한 분해능이 확인되었 다. 하지만 모든 시료로부터 $\mathrm{BA}$ 분해능이 있는 효모는 분리 되지 않았다. 특히, L. sakei MML23과 P. pentosaceus SML34로부터 인공 위액과 담즙액에 대한 저항성, 장관 상피 세포에 대한 부착능 및 특정 항생제에 대한 높은 감수성 등의 프로바이오틱 활성이 확인되었다. 또한, 프로바이오틱 균주로 추정되는 유산균들이 생산한 박테리오신은 일부 BA 생성균 에 대한 항균 활성을 나타내었다. 결론적으로 프로바이오틱 $L$. sakei MML23과 P. pentosaceus SML34가 생산한 박테리오신 은 히스타민, 카다베린 및 푸트레신 생성균의 성장을 억제시 킴으로써 $\mathrm{BA}$ 독성의 위험을 감소시키는데 효과적인 것으로 나타났다.

\section{감사의 말}

이 논문은 2019학년도 동명대학교 교내학술연구비 지원에 의하여 연구되었음(과제번호 2019A036).

\section{Conflict of interests}

The authors declare no potential conflict of interest.

\section{ORCID}

Eun-Seo Lim https://orcid.org/0000-0001-9645-7408

\section{References}

Allameh SK, Yusoff FM, Daud HM, Ringo E, Ideris Am Saad CR. Characterization of a probiotic Lactobacillus fermentum isolated from snakehead, Channa striatus, stomach. J World Aquacult Soc, 44, 835-844 (2013)

Arena ME, Fiocco D, Manca de Nardra MC, Pardo I, Spano G. Characterization of a Lactobacillus plantarum strain able to produce tyramine and partial cloning of a putative tyrosine decarboxylase gene. Curr Microbiol, 55, 205-210 (2007)

Barbieri F, Montanari C, Gardini F, Tabanelli G. Biogenic amine production by lactic acid bacteria: A review. Foods, 8, 17, (2019)

Bauer AW, Kirby WM, Sherris JC, Turck M. Antibiotic susceptibility testing by standardized single disc diffusion method. Am J Clin Pathol, 45, 493-496 (1966)

Bäumlisberger M, Moellecken U, Konig H, Claus H. The potential of the yeast Debaryomyces hansenii H525 to degrade biogenic amines in food. Microorganisms, 3, 839-850 (2015)

Benkerroum N. Biogenic amines in dairy products: origin, incidence, and control means. Compr Rev Food Sci Food Saf, 15, 801-826 (2016)

Caruso M, Fiore C, Contursi M, Salzano G, Paparella A, Romano P. Formation of biogenic amines as criteria for the selection of wine yeasts. World $\mathrm{J}$ Microbiol Biotechnol, 18, 159-163 (2002)

Cousin FJ, Mater DDG, Foligne B, Jan G. Dairy propionibacteria as human probiotics: A review of recent evidence. Dairy Sci Technol, 91, 1-26 (2011)

Dimidi E, Cox SR, Rossi M, Whelan K. Fermented foods: Definitions and characteristics, impact on the gut microbiota and effects on gastrointestinal health and disease. Nutrients, 11, 1806 (2019)

Doeun D, Davaatseren M, Chung MS. Biogenic amines in foods. Food Sci Biotechnol, 26, 1463-1474 (2017)

Eerola HS, Roig-Sagues AX, Hirvi TK. Biogenic amines in finnish dry sausages. J Food Saf, 18, 127-138 (1998) Garcia-Ruiz A, Gonzalez-Rompinelli EM, Bartolome B, 
Moreno-Arribas MV. Potential of wine-associated lactic acid bacteria to degrade biogenic amines. Int $\mathrm{J}$ Food Microbiol, 148, 115-120 (2011)

Han GH, Cho TY, Yoo MS, Kim CS, Kim JM, Kim HA, Kim MO, Kim SC, Lee SA, Ko YS, Kim SH, Kim DB. Biogenic amines formation and content in fermented soybean paste (Cheonggukjang). Korean J Food Sci Technol, 39, 541-545 (2007)

Jin YH, Lee JH, Park YK, Lee JH, Mah JH. The occurrence of biogenic amines and determination of biogenic amine-producing lactic acid bacteria in Kkakdugi and Chonggak kimchi. Foods, 8, 73, (2019)

Kang SE, Kim MJ, Kim TW. Diversity and role of yeast on kimchi fermentation. J Korean Soc Food Cult, 34, 201-207 (2019)

Khiralla GM. Cholesterol degradation by some bacteria isolated from food. Food Sci Technol Res, 21, 685-693 (2015)

Kim MJ, Kim KS. Tyramine production among lactic acid bacteria and other species isolated from kimchi. LWTFood Sci Technol, 56, 406-413 (2014)

Kim SH, Kim SH, Kang KH, Lee S, Kim SJ, Kim JG, Chung MJ. Kimchi probiotic bacteria contribute to reduced amounts of $N$-nitrosodimethylamine in lactic acid bacteria- fortified kimchi. LWT-Food Sci Technol, 84, 196-203 (2017)

Ladero V, Calles-Enriquez M, Fernandez M, Alvarez MA. Toxicological effects of dietary biogenic amines. Curr Nutr Food Sci, 6, 145-156 (2010)

Lee JG, Lee GJ, Lim SM. Partial purification of bacteriocin produced by Enterococcus faecium MJ-14 isolated from Meju. J Food Hyg Saf, 20, 211-216 (2005)

Lee JH, Jin YH, Park YK, Yun SJ, Mah JH. Formation of biogenic amines in $\mathrm{Pa}$ (green onion) kimchi and Gat (mustard leaf) kimchi. Foods, 8, 109, (2019)

Lee KH, Lee JH. Isolation of Leuconostoc and Weissella species inhibiting the growth of Lactobacillus sakei from kimchi. Korean J Microbiol Biotechnol, 39, 175-181 (2011)

Lee KW, Shim JM, Yao Z, Kim JA, Kim JH. Properties of kimchi fermented with GABA-producing lactic acid bacteria as a starter. J Microbiol Biotechnol, 28, 534-541 (2018)

Lee YC, Lin CS, Liu FL, Huang TC, Tsai YH. Degradation histamine by Bacillus polymyxa isolated from salted fish products. J Food Drug Anal, 23, 836-844 (2015)

Lertworapreecha N, Poonsuk K, Chalermchiakit T. Selection of potential Enterococcus faecium isolated from Thai native chicken for probiotic use according to the in vitro properties. Songklanakari J Sci Technol, 33, 9-14 (2011)

Li H, Cao Y. Lactic acid bacterial cell factories for gammaaminobutyric acid. Amino Acids, 39, 1107-1116 (2010)

Lim ES. Evaluation of microbial contamination levels and biogenic amines content in over-ripened kimchi. Korean J Food Preserv, 27, 637-650 (2020)

Lim ES. Antibacterial activity of lactic acid bacteria against biogenic amine-producing Bacillus spp. isolated from traditional fermented soybean paste. Korean J Microbiol, 54, 398-409 (2018)

Lim ES. Effect of the mixed culture of heterfermentative lactic acid bacteria and acid-tolerant yeast on the shelf-life of sourdough. Korean J Microbiol, 52, 471-481 (2016)

Lim ES. Isolation, identification, and probiotic characteristics of Bacillus strains affecting the biogenic amine content in fermented soybean paste. Korean J Microbiol, 55, 131-142 (2019)

Liu L, Guan N, Li J, Shin H, Du G, Chen J. Development of GRAS strains for nutraceutical production using systems and synthetic biology approaches: Advances and prospects. Crit Rev Biotechnol, 37, 139-150 (2017)

Lucas PM, Blancato VS, Claisse O, Magni C, Lolkema JS, Lonvaud-Funel A. Agmatine deiminase pathway genes in Lactobacillus brevis are linked to the tyrosine decarboxylation operon in a putative acid resistance locus. Microbiology, 153, 2221-2230 (2007)

Mah JH, Ahn JB, Park JH, Sung HC, Hwang HJ. Characterization of biogenic amine-producing microorganisms isolated from Myeolchi-jeot, Korean salted and fermented anchovy. J Microbiol Biotechnol, 13, 692-699 (2003)

Mah JH, Kim YJ, No HK, Hwang HJ. Determination of biogenic amines in kimchi, Korean traditional fermented vegetable products. Food Sci Biotechnol, 13, 826-829 (2004)

Mah JH, Park YK, Jin YH, Lee JH, Hwang HJ. Bacterial production and control of biogenic amines in Asian fermented soybean foods. Foods, 8, 85 (2019)

Min JH, Hyun SH, Kang MG, Lee HB, Kim CM, Kim HK, 
Lee JS. Isolation and identification of yeasts from wild flowers of Daejeon city and Chungcheongnam-do in Korea. Kor J Mycol, 40, 141-144 (2012)

Montet D, Ray RC, Zakhia-Rozia N. Lactic acid fermentation of vegetables and fruits. In: Microorganisms and Fermentation of Traditional Foods, Ray RC, Montet D (Editor), CRC Press, Boca Raton, Florida, USA, p 108-140 (2014)

Niu T, Li X, Guo Y, Ma Y. Identification of a lactic acid bacteria to degrade biogenic amines in Chinese rice wine and its enzymatic mechanism. Foods, 8, 312 (2019)

Panicker AS, Ali SA, Anand S, Panjagari NR, Kumar S, Mohanty AK, Behare PV. Evaluation of some in vitro probiotic properties of Lactobacillus fermentum strains. J Food Sci Technol, 55, 2801-2807 (2018)

Park JH, Oh DH, Chung HY. Antimicrobial activity of Lactobacillus sakei J4 isolated from Korean Dongchimi and its probiotic properties. Food Eng Prog, 16, 122-128 (2012)

Park JM, Shin JH, Lee DW, Song JC, Suh HJ, Chang UJ, Kim JM. Identification of the lactic acid bacteria in kimchi according to initial and over-ripened fermentation using PCR and 16S rRNA gene sequence analysis. Food Sci Biotechnol, 19, 541-546 (2010)

Park KY, Jeong JK, Lee YE, Daily JW. Health benefits of kimchi (Korean fermented vegetables) as a probiotic food. J Med Food, 17, 6-20 (2014)

Qi W, Hou LH, Guo HL, Wang CL, Fan ZC, Liu JF, Cao XH. Effect of salt-tolerant yeast of Candida verstilis and Zygosaccharomyces rouxii on the production of biogenic amines during soy sauce fermentation. J Sci Food Agric, 94, 1537-1542 (2014)

Rhee SJ, Lee JE, Lee CH. Importance of lactic acid bacteria in Asian fermented foods. Microb Cell Fact, 10, S5 (2011)

Seo SH, Jung MR, Kim WJ. Antilisterial and amylasesensitive bacteriocin producing Enterococcus faecium SH01 from Mukeunji, a Korean over-ripened kimchi. Food Sci Biotechnol, 23, 1177-1184 (2014)

Shakila RJ, Vasundhara TS, Rao DV. Inhibitory effect of spices on in vitro histamine production and histidine decarboxylase activity of Morganella morganii and on the biogenic amine formation in mackerel stored at $30^{\circ} \mathrm{C}$. Z Lebensm Unters Forsch, 203, 71-76 (1996)

Song MY, Yun BH, Moon JH, Park DJ, Lim KS, Oh SJ. Characterization of selected Lactobacillus strains for use as probiotics. Korean J Food Sci Anim Resour, 35, 551-556 (2015)

Spano G, Russo P, Lonvau-Funel A, Lucas P, Alexandre H, Grandvalet C, Coton E, Coton M, Barnavon L, Bach B, Rattray F, Bunte A, Magni C, Ladero V, Alvarez M, Fernandez M, Lopez P, de Palencia PF, Corbi A, Trip $\mathrm{H}$, Lolkema JS. Biogenic amines in fermented foods. Eur J Clin Nutr, 64, S95-S100 (2010)

Tabanellin G, Montanari C, Bargossi E, Lanciotti R, Gatto V, Felis G, Torriani S, Gardini F. Control of tyramine and histamine accumulation by lactic acid bacteria using bacteriocin forming lactococci. Int J Food Microbiol, 190, 14-23 (2014)

Tamang JP, Shin DH, Jung SJ, Chae SW. Functional properties of microorganisms in fermented foods. Front Microbiol, 7, 578 (2016)

Tsai YH, Kung HF, Lin QL, Hwang JH, Cheng SH, Wei CI, Hwang DF. Occurrence of histamine and histamineforming bacteria in kimchi products in Taiwan. Food Chem, 90, 635-641 (2005)

Um IS, Kim TO, Kim HD, Park KS. Characterization of tryptamine-producing bacteria isolated from commercial salted and fermented sand lance Ammodytes personatus sauces. Korean J Fish Aquat Sci, 49, $792-799$ (2016)

Urs VSR, Ramlal S, Batra HV, Naika M, Jeyabalaji JK. An in-vitro screening for biogenic amines producing microorganisms from fermented foods and its degradation by bacteria from canine saliva. J Pure Appl Microbiol, 13, 271-280 (2019)

Zhao W, Liu Y, Latta M, Ma W, Wu Z, Chen P. Probiotic database: a potential source of fermented foods. Int $\mathrm{J}$ Food Prop, 22, 198-217 (2019)

Zommiti M, Bouffartigues E, Maillot O, Barreau M, Szunerits S, Sebei K, Feuilloley M, Connil N, Ferchichi M. In vitro assessment of the probiotic properties and bacteriocinogenic potential of Pediococcus pentosaceus MZF16 isolated from artisanal Tunisian meat "Dried Ossban”. Front Microbiol, 9, 2607 (2018) 